\title{
ERBB4 Gene Mutation
}

National Cancer Institute

\section{Source}

National Cancer Institute. ERBB4 Gene Mutation. NCI Thesaurus. Code C138060.

A change in the nucleotide sequence of the ERBB4 gene. 